\title{
Nautella italica gen. nov., sp. nov., isolated from a marine electroactive biofilm
}

\author{
Ilse Vandecandelaere, ${ }^{1}$ Olivier Nercessian, ${ }^{2}$ Eveline Segaert, ${ }^{1}$ \\ Wafa Achouak, ${ }^{2}$ Alfonso Mollica, ${ }^{3}$ Marco Faimali ${ }^{3}$ and Peter Vandamme ${ }^{1}$
}

Correspondence Ilse Vandecandelaere Ilse.Vandecandelaere@UGent.be

\author{
${ }^{1}$ Laboratorium voor Microbiologie, Vakgroep Biochemie, Fysiologie en Microbiologie, Universiteit \\ Gent, K. L. Ledeganckstraat 35, B-9000 Gent, Belgium \\ ${ }^{2}$ LEMiR, Laboratoire d'Ecologie Microbienne de la Rhizosphère, CNRS-CEA-Université de la \\ Méditerranée, DEVM, Département d'Ecophysiologie Végétale et de Microbiologie/DSV CEA \\ Cadarache, F-13108 Saint-Paul-lès-Durance, France \\ ${ }^{3}$ Istituto di Scienze Marine-Consiglio Nazionale delle Ricerche (ISMAR-CNR), Via de Marini 6, \\ I-16149 Genoa, Italy
}

\begin{abstract}
Five isolates obtained from a marine electroactive biofilm grown on a stainless steel cathode were investigated by using a polyphasic taxonomic approach. Analyses of whole-cell fatty acid methyl esters and 16S rRNA gene sequences showed that the isolates belonged to the Roseobacter lineage of the class Alphaproteobacteria. Both phenotypic and genotypic analyses demonstrated that the five new isolates constituted a single species that did not represent a recognized member of the Roseobacter lineage. Therefore the five isolates represent a novel genus and species, for which the name Nautella italica gen. nov., sp. nov. is proposed. The type strain is LMG $24365^{\top}$ $\left(=\right.$ CCUG $55857^{\top}$ ). The DNA G + C content of the type strain is $61 \mathrm{~mol} \%$.
\end{abstract}

The Roseobacter lineage of the class Alphaproteobacteria is one of the most predominant marine bacterial groups, representing up to $20 \%$ of coastal, and up to $15 \%$ of mixedlayer, bacterioplankton populations (González \& Moran, 1997; González et al., 2000; Selje et al., 2004; Suzuki et al., 2001). Members of the Roseobacter lineage are found in almost every marine environment, i.e. from coastal seawater to open-ocean seawater and from sea ice to sea-floor sediments (e.g. Brinkmeyer et al., 2003; González \& Moran, 1997; Inagaki et al., 2003; Selje et al., 2004). They exhibit a diverse range of metabolic and physiological characteristics, including aerobic anoxygenic phototrophy (Shiba, 1991), sulphur transformations (Moran et al., 2003), carbon monoxide oxidation (King, 2003; Moran et al., 2004) and degradation of aromatic compounds (Buchan et al., 2000; González et al., 1996). Several studies have indicated an important role for roseobacters in the formation of marine biofilms (Dang \& Lovell, 2000) in which they use the production of antibiotics and secondary metabolites to outcompete other bacteria (Martens et al., 2007).

The present study was part of an analysis of the microbial diversity of a marine electroactive biofilm (EAB) which was grown on a stainless steel cathode exposed to natural

Abbreviation: EAB, electroactive biofilm.

The GenBank/EMBL/DDBJ accession numbers for the 16S rRNA gene sequences of strains LMG $24365^{\top}$, LMG 24364, R-25532, R-28717 and R-28753 are AM904562, AM904563, AM944520, AM944521 and AM944522, respectively. seawater at the ISMAR-CNR Marine Station, located in the port of Genoa, Italy (Faimali et al., 2008; Vandecandelaere et al., 2008). The biofilm was removed from the stainless steel cathode by sonication (3200; Branson) for $90 \mathrm{~s}$ in a sterile plastic tube containing $30 \mathrm{ml} 0.85 \% \mathrm{NaCl}$ solution. Diluted cell suspensions $\left(10^{-1}\right.$ to $\left.10^{-6}\right)$ were inoculated onto marine agar 2216 (MA; Difco) and incubated aerobically at $20{ }^{\circ} \mathrm{C}$ for 3 days. Pure cultures were obtained from initial isolation plates and were inoculated onto MA; pure cultures were stored at $-80{ }^{\circ} \mathrm{C}$ using Microbank vials.

All isolates were investigated by analysing the whole-cell fatty acid methyl esters as described by Mergaert et al. (2001). Comparison of the fatty acid methyl ester profiles of the five isolates with those available in a commercial (MIS) database led to the tentative identification of these strains as members of the genus Paracoccus, with low to moderate identification scores $(0.192-0.361)$. The predominant fatty acids were as follows: $\mathrm{C}_{18: 1} \omega 7 c(74.5 \pm 3.6 \%)$, $\mathrm{C}_{16: 0} \quad 2-\mathrm{OH} \quad(5.5 \pm 0.7 \%)$, 11-methyl $\mathrm{C}_{18: 1} \omega 7 c \quad(4.5 \pm$ $2.5 \%)$, an unknown fatty acid with an equivalent chainlength of $11.799(3.6 \pm 0.4 \%), \mathrm{C}_{10: 0} 3-\mathrm{OH}(3.2 \pm 0.4 \%)$, $\mathrm{C}_{18: 0} \quad 12-\mathrm{OH} \quad(2.6 \pm 0.6 \%), \mathrm{C}_{12: 0} \quad 3-\mathrm{OH} \quad(2.4 \pm 0.3 \%)$, $\mathrm{C}_{16: 0}(1.8 \pm 0.3 \%)$ and $\mathrm{C}_{18: 0}(1.4 \pm 0.3 \%)$; the remaining fatty acids constituted $<1.0 \%$ (Table 1 ).

DNA was extracted as described by Pitcher et al. (1989). Almost-complete 16S rRNA gene sequences (1425$1432 \mathrm{bp}$ ) were obtained for the five isolates (LMG 24364, LMG $24365^{\mathrm{T}}, \mathrm{R}-28717, \mathrm{R}-28753$ and R-25532) using the 
Table 1. Fatty acid content (\%) of strains LMG $24365^{\top}$ and LMG 24364 and the type strains of related species

Taxa: 1, strains LMG $24365^{\mathrm{T}}$ and LMG 24364; 2, Phaeobacter inhibens; 3, Phaeobacter gallaeciensis; 4, Phaeobacter daeponensis; 5, Leisingera methylohalidivorans; 6, Ruegeria atlantica. -, Fatty acids constituting $<1 \%$; ND, no data available.

\begin{tabular}{|c|c|c|c|c|c|c|}
\hline Fatty acid & 1 & 2 & 3 & 4 & 5 & 6 \\
\hline \multicolumn{7}{|c|}{ Straight-chain fatty acids } \\
\hline $\mathrm{C}_{16: 0}$ & $1.8 \pm 0.3$ & 3.83 & 3.79 & 8.6 & 5.08 & 6.25 \\
\hline $\mathrm{C}_{18: 0}$ & $1.4 \pm 0.3$ & 3.14 & 2.57 & 2.4 & - & 2.28 \\
\hline \multicolumn{7}{|c|}{ Unsaturated fatty acids } \\
\hline $\mathrm{C}_{14: 1}$ & ND & 2.19 & 2.14 & ND & 2.27 & $\mathrm{ND}$ \\
\hline $\mathrm{C}_{18: 1} \omega 7 c$ & $74.5 \pm 3.6$ & 73.77 & 75.51 & 57.7 & 70.27 & 45.53 \\
\hline \multicolumn{7}{|c|}{ Hydroxy fatty acids } \\
\hline $\mathrm{C}_{10: 0} 3-\mathrm{OH}$ & $3.2 \pm 0.4$ & 1.71 & 1.86 & 1.7 & 1.83 & - \\
\hline $\mathrm{C}_{12: 0} 3-\mathrm{OH}$ & $2.4 \pm 0.3$ & 1.59 & 1.27 & 2.6 & 2.27 & 8.67 \\
\hline $\mathrm{C}_{16: 0} 2-\mathrm{OH}$ & $5.5 \pm 0.7$ & 3.10 & 3.90 & 5.6 & 6.97 & 10.44 \\
\hline $\mathrm{C}_{18: 0} 12-\mathrm{OH}$ & $2.6 \pm 0.6$ & $\mathrm{ND}$ & $\mathrm{ND}$ & $\mathrm{ND}$ & $\mathrm{ND}$ & $\mathrm{ND}$ \\
\hline $\begin{array}{l}\text { 11-Methyl } \\
\mathrm{C}_{18: 1} \omega 7 c\end{array}$ & $4.5 \pm 2.5$ & 7.45 & 6.60 & 16.6 & 6.86 & 30.40 \\
\hline
\end{tabular}

universal primers pA (5'-AGAGTTTGATCCTGGCTCAG$\left.3^{\prime}\right)$ and $\mathrm{pH}$ (5'-AAGGAGGTGATCCAGCCGCA-3') (Edwards et al., 1989) as described previously (Mergaert et al., 2001). The most similar sequences in the public databases were found using FASTA. The sequences were aligned using CLUSTAL_X (Thompson et al., 1997) and edited using BioEdit (Hall, 1999) and ForCon (Raes \& Van De Peer, 1999).

Numerical analysis showed that isolates LMG $24365^{\mathrm{T}}$, LMG 24364, R-28753, R-28717 and R-25532 shared $100 \%$ 16S rRNA gene sequence similarity. The recognized species of the genus Phaeobacter [Phaeobacter inhibens, Phaeobacter daeponensis and Phaeobacter gallaeciensis (at the time of writing)] were found to be their closest phylogenetic neighbours, although the 16S rRNA gene sequence similarities were relatively low (96.6-97.2\%, but mainly $<97 \%)$. A neighbour-joining dendrogram was constructed (Saitou \& Nei, 1987) using TREECON (Van De Peer \& De Wachter, 1994) (Fig. 1) and the tree topology was confirmed by maximum-parsimony and maximum-likelihood analyses (data not shown).

DNA-DNA hybridization experiments were performed with isolates LMG $24365^{\mathrm{T}}$, LMG 24364 and representatives of their closest neighbours, using photobiotin-labelled probes in microplate wells, as described by Ezaki et al. (1989), and a HTS7000 Bio Assay Reader (Perkin Elmer) for the fluorescence measurements. The hybridization temperature was $45{ }^{\circ} \mathrm{C}$ and reciprocal reactions were performed for every pair of strains. The DNA-DNA hybridization values between strains LMG $24365^{\mathrm{T}}$ and LMG 24364 were high, i.e. $>70 \%(88 \pm 5 \%)$. The DNADNA hybridization values between strain LMG $24365^{\mathrm{T}}$ and the type strains of $P$. gallaeciensis, $P$. daeponensis and $P$. inhibens were low, ranging from $7 \pm 2 \%$ to $17 \pm 0 \%$. These data demonstrate that the five new isolates constitute a novel species, which is best allocated to a novel genus within the Roseobacter lineage of the class Alphaproteobacteria (Fig. 1).

The genetic diversity of the five isolates was examined by repetitive extragenic palindromic DNA-PCR fingerprinting using the BOX-A1R primer (5'-CTACGGCAAGGCGACGCTGACG-3') (Rademaker \& De Bruijn, 1997; Versalovic et al., 1994). Differences between the BOX-PCR fingerprints of all five isolates were observed, indicating the presence of five genetically distinct strains (Fig. 2).

DNA was subsequently enzymically degraded into nucleosides as described by Mesbah et al. (1989). The nucleoside mixture obtained was then separated using a Water Breeze HPLC system and an Xbridge Shield RP18 column thermostabilized at $37{ }^{\circ} \mathrm{C}$. The solvent was $0.02 \mathrm{M}$ $\mathrm{NH}_{4} \mathrm{H}_{2} \mathrm{PO}_{4}$ (pH 4.0) with $1.5 \%$ acetonitrile. Non-methylated lambda phage (Sigma) and Escherichia coli LMG 2093 DNA samples were used as the calibration reference and control, respectively. The DNA G $+\mathrm{C}$ contents of strains LMG $24365^{\mathrm{T}}$ and LMG 24364 were $61.0 \pm 0.8 \%$.

The following morphological, physiological and biochemical characteristics were determined for strains LMG $24365^{\mathrm{T}}$ and LMG 24364. Colony morphology (i.e. determination of the surface, edge and transparency features) was examined microscopically ( $\times 40$ magnification) after 4 days incubation at $20{ }^{\circ} \mathrm{C}$ on MA. Cells were tested for their Gram reaction, catalase activity and oxidase activity. Growth was verified on nutrient agar, trypticase soy agar, R2A agar and peptone/yeast extract/glucose agar (Tan \& Rüger, 1999). The optimal salinity was determined using R2A agar supplemented with $1-20 \% \mathrm{NaCl}$; plates were incubated for 2 weeks at $20{ }^{\circ} \mathrm{C}$. The optimal growth temperature was determined on MA incubated at $4-45{ }^{\circ} \mathrm{C}$ for 2 weeks. The effect of $\mathrm{pH}$ on growth was tested at $\mathrm{pH}$ 5.0-10.0 (using increments of $0.5 \mathrm{pH}$ units) in marine broth 2216 (Difco) incubated at $20{ }^{\circ} \mathrm{C}$ for 7 days. Growth was checked by measuring optical density at $600 \mathrm{~nm}$.

Degradation of casein and chitin (Reichenbach \& Dworkin, 1981), DNA [using DNA agar (Difco) containing 0.01\% toluidine blue (Merck)], starch and L-tyrosine (Barrow \& Feltham, 1993) was tested after 5 days incubation at $20{ }^{\circ} \mathrm{C}$. To determine their lipolytic activity, the isolates were inoculated onto Sierra's medium and incubated for 10 days at $20{ }^{\circ} \mathrm{C}$ (Sierra, 1957).

Susceptibility to the following antibiotics (from Oxoid) was tested on MA plates, using the diffusion disc method: cefoxitin $(30 \mu \mathrm{g})$, gentamicin $(10 \mu \mathrm{g})$, erythromycin $(15 \mu \mathrm{g})$, streptomycin $(25 \mu \mathrm{g})$, tetracycline $(30 \mu \mathrm{g})$, vancomycin $(30 \mu \mathrm{g})$, trimethoprim $(1.25 \mu \mathrm{g})$ and clindamycin $(2 \mu \mathrm{g})$. Results were read after 5 days incubation at $20{ }^{\circ} \mathrm{C}$.

Biochemical characteristics were determined using commercial microtest galleries (API ZYM and API 20NE) 
$\underline{1 \%}$

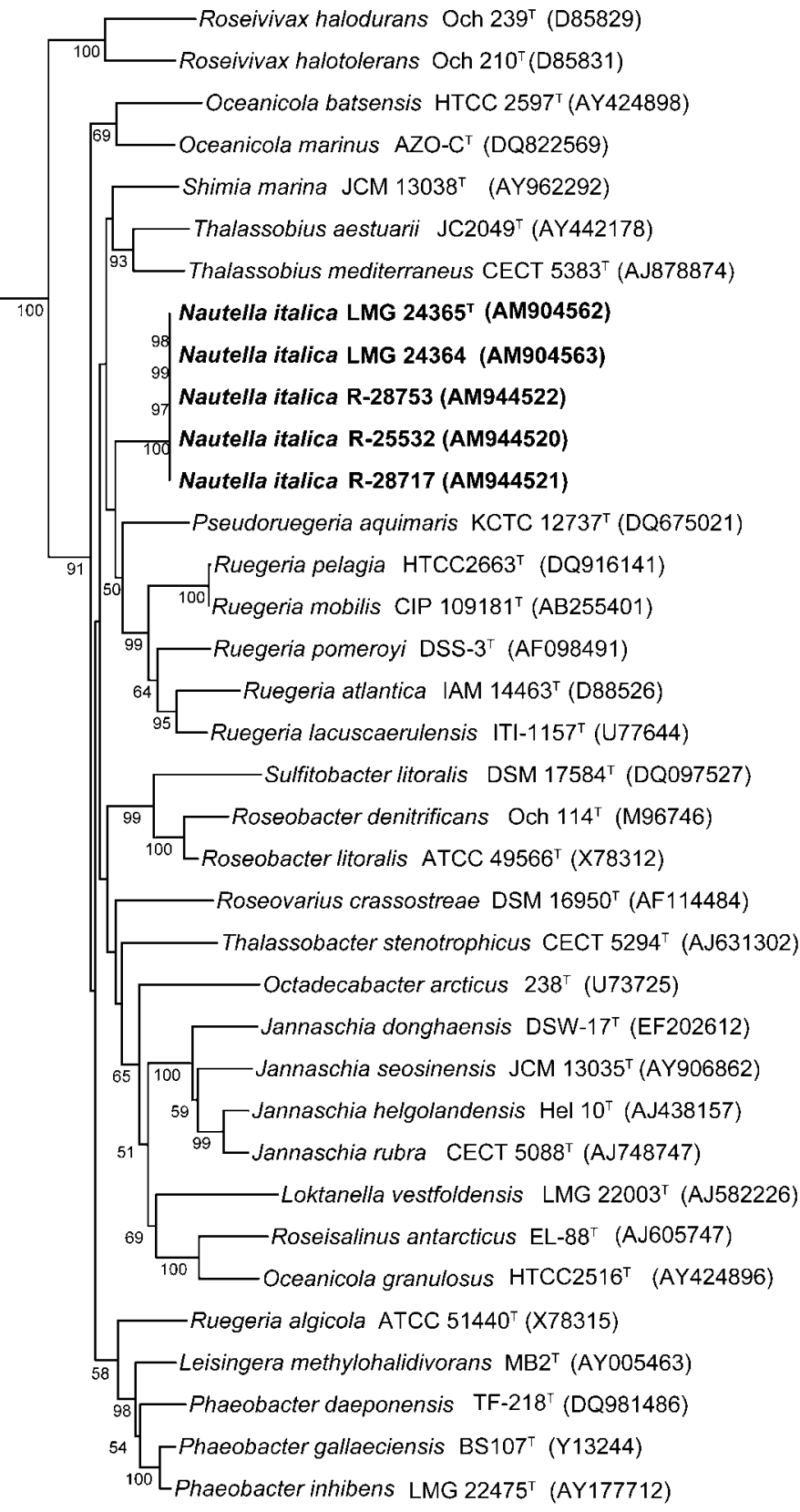

Aeromonas hydrophila subsp. bestiarum ATCC $7966^{\top}(X 74677)$
Fig. 1. Neighbour-joining dendrogram, based on 16S rRNA gene sequences, showing the phylogenetic positions of strains LMG $24365^{\top}$, LMG 24364, R-25532, R-28717 and R28753 and their closest neighbours. Bar, $1 \%$ sequence divergence.

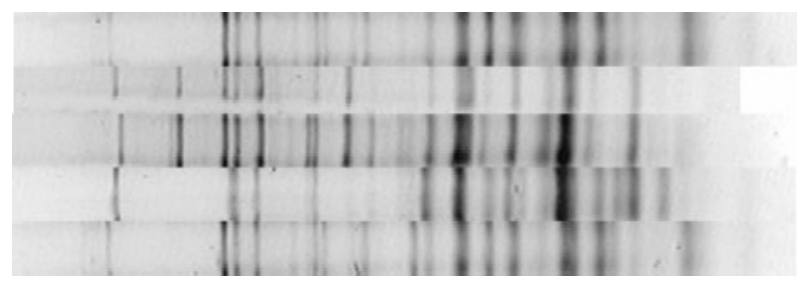

LMG $24365^{\top}$

R-28717

R-28753

R-25532

LMG 24364
Fig. 2. $B O X-P C R$ fingerprints of strains $L M G$ $24365^{\top}$, LMG 24364, R-25532, R-28717 and R-28753. 
according to the manufacturer's instructions (bioMérieux). API ZYM was used to determine the enzymic activities of the isolates investigated; the results were read after $4 \mathrm{~h}$ incubation at $20{ }^{\circ} \mathrm{C}$. The API $20 \mathrm{NE}$ results were read after $48 \mathrm{~h}$ incubation at $20^{\circ} \mathrm{C}$.

The cell morphology of strain LMG $24365^{\mathrm{T}}$ was determined using transmission electron microscopy. Cells were negatively stained with $2 \%$ uranyl acetate. Ultrathin sections were prepared and analysed as described by Mast et al. (2005) (Fig. 3).

The results of the phenotypic tests are summarized in Table 2. In conclusion, we have demonstrated that the five isolates represent genetically distinct strains constituting a novel species within a novel genus, for which we propose the name Nautella italica gen. nov., sp. nov.

\section{Description of Nautella gen. nov.}

Nautella (Naut.el.la. L. n. nauta seaman; L. dim. suf. -ella; N.L. fem. n. Nautella the small seaman, referring to the marine habitat of this novel bacterial genus).

Gram-negative, motile rods that are moderately halophilic and strictly aerobic. Catalase- and oxidase-positive. The temperature range for growth is $4-45{ }^{\circ} \mathrm{C}$. The type species is Nautella italica.
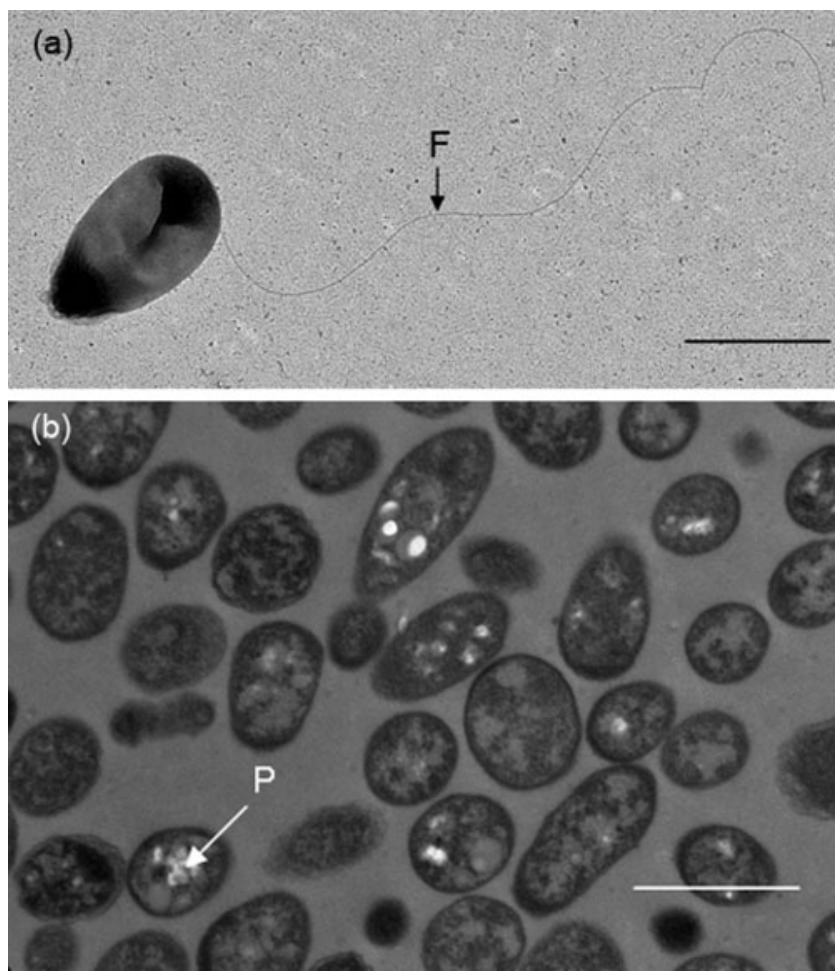

Fig. 3. Electron micrographs of cells of strain LMG $24365^{\top}$, showing (a) a polar flagellum (F) and (b) poly- $\beta$-hydroxybutyrate (P) inclusion bodies. Bars, $1 \mu \mathrm{m}$.

\section{Description of Nautella italica sp. nov.}

Nautella italica (i.ta'li.ca. L. fem. adj. italica from Italy, where this species was first isolated).

Cells are Gram-negative rods $(0.7-0.11 \times 1.5-2.1 \mu \mathrm{m})$ that are motile by means of a single polar flagellum. Poly- $\beta$-hydroxybutyrate inclusion bodies are observed (Fig. 3). Colonies are beige, round and $1-2 \mathrm{~mm}$ in diameter after 3 days incubation on $\mathrm{MA}$ at $20{ }^{\circ} \mathrm{C}$. Colonies have a smooth surface and are convex with entire margins. Growth occurs after 2 days at $20{ }^{\circ} \mathrm{C}$ on $\mathrm{MA}$, but not on trypticase soy agar, R2A agar, nutrient agar or peptone/yeast extract/glucose agar. The temperature range for growth is $4-45^{\circ} \mathrm{C}$ (growth at $4{ }^{\circ} \mathrm{C}$ is weak). The optimal growth temperature is $20-28{ }^{\circ} \mathrm{C}$. Moderately halophilic $(1-5 \% \mathrm{NaCl})$; only weak growth occurs in the presence of $7 \% \mathrm{NaCl}$ and no growth occurs in the absence of $\mathrm{NaCl}$. The optimal salinity is $2-3 \%$ $\mathrm{NaCl}$. The $\mathrm{pH}$ range for growth is 5.5-9.0 and the optimal $\mathrm{pH}$ for growth is 6.5-8.0. Catalase- and oxidase-positive. Degrades Tween 80 and aesculin (API 20NE), but not tyrosine, DNA, starch, chitin, gelatin (API 20NE) or casein. Activity was recorded for leucine arylamidase, alkaline phosphatase, acid phosphatase, naphthol-AS-BIphosphohydrolase and $\alpha$-glucosidase. Weak enzymic activity was observed for esterase lipase (C8), valine arylamidase, $\alpha$-galactosidase and $\beta$-glucosidase. Variable results were obtained for $\beta$-glucuronidase. No activity was detected for esterase (C4), $N$-acetyl- $\beta$-glucosamidase, $\alpha$-mannosidase, lipase (C14), cystine arylamidase, trypsin, $\alpha$-chymotrypsin, arginine hydrolase, urease or $\alpha$-fucosidase. Nitrate is not reduced to nitrite (API 20NE). Indole is not produced and glucose is not fermented (API 20NE). No assimilation of D-glucose, L-arabinose, Dmannose, D-mannitol, $\mathrm{N}$-acetylglucosamine, maltose, potassium gluconate, capric acid, adipic acid, malate, citrate or phenylacetic acid (API 20NE) is detected. Susceptible to cefoxitin $(30 \mu \mathrm{g})$, erythromycin $(15 \mu \mathrm{g})$ and streptomycin $(25 \mu \mathrm{g})$, moderately susceptible to tetracycline $(30 \mu \mathrm{g})$ and resistant to gentamicin $(30 \mu \mathrm{g})$, vancomycin $(30 \mu \mathrm{g})$, trimethoprim $(1.25 \mu \mathrm{g})$ and clindamycin $(2 \mu \mathrm{g})$. The predominant fatty acids are $\mathrm{C}_{18: 1} \omega 7 c, \mathrm{C}_{16: 0} 2-\mathrm{OH}, 11-$ methyl $\mathrm{C}_{18: 1} \omega 7 c$, an unknown fatty acid with an equivalent chain-length of $11.799, \mathrm{C}_{10: 0}$ 3-OH, $\mathrm{C}_{18: 0} 12-\mathrm{OH}, \mathrm{C}_{12: 0} 3-\mathrm{OH}, \mathrm{C}_{16: 0}$ and $\mathrm{C}_{18: 0}$. The DNA G $+\mathrm{C}$ content is $61.0 \pm 0.8 \mathrm{~mol} \%$.

The type strain, LMG $24365^{\mathrm{T}}$ (=CCUG $55857^{\mathrm{T}}$ ), and four additional strains (LMG 24364, R-25532, R-28717 and R28753) were obtained from a marine electroactive biofilm in Genoa, Italy.

\section{Acknowledgements}

This work was funded by the European Commission [EA BIOFILMS508866 (NEST)]. The Fund for Scientific Research-Flanders (FWOVlaanderen) is acknowledged for the financial support of P.V. 
Table 2. Summary of the phenotypic characteristics of strains LMG $24365^{\top}$ and LMG 24364 and the type species of the genera Leisingera, Ruegeria and Phaeobacter

Strains: 1, LMG 24365 ${ }^{\mathrm{T}}$ and LMG 24364; 2, P. inhibens LMG 22475 ${ }^{\mathrm{T}}$ (Martens et al., 2006); 3, P. gallaeciensis LMG 23163 ${ }^{\mathrm{T}}$ (Martens et al., 2006;

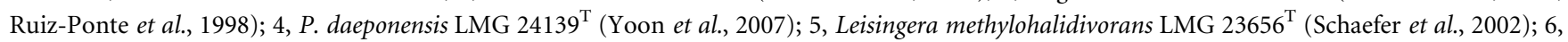
Ruegeria atlantica LMG $23161^{\mathrm{T}}$ (Martens et al., 2006; Rüger \& Höfle, 1992; Uchino et al., 1998). +, Positive; -, negative; w, weak activity; M, moderately susceptible; ND, no data available. All strains were susceptible to streptomycin $(25 \mu \mathrm{g})$.

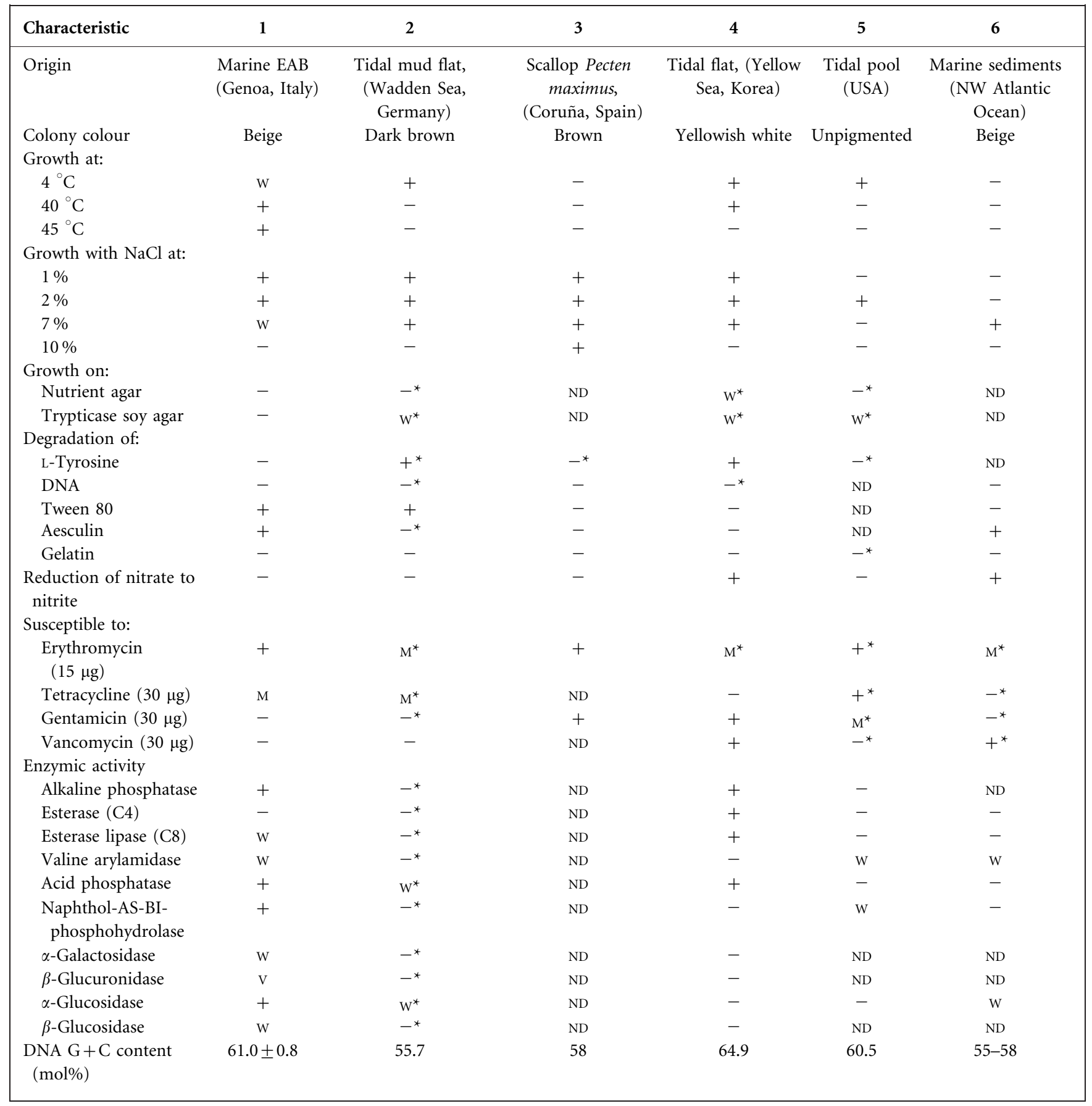

${ }^{\star}$ Data from this study. 


\section{References}

Barrow, G. I. \& Feltham, R. K. A. (1993). Cowan and Steel's Manual for the Identification of Medical Bacteria, 3rd edn. Cambridge: Cambridge University Press.

Brinkmeyer, R., Knittel, K., Jürgens, J., Weyland, H., Amann, R. \& Helmke, E. (2003). Diversity and structure of bacterial communities in Arctic versus Antarctic pack ice. Appl Environ Microbiol 69, 66106619.

Buchan, A., Collier, L. S., Neidle, E. L. \& Moran, M. A. (2000). Key aromatic-ring-cleaving enzyme, protocatechuate 3,4-dioxygenase, in the ecologically important marine Roseobacter lineage. Appl Environ Microbiol 66, 4662-4672.

Dang, H. \& Lovell, C. R. (2000). Bacterial primary colonization and early succession on surfaces in marine waters as determined by amplified rRNA gene restriction analysis and sequence analysis of $16 \mathrm{~S}$ rRNA genes. Appl Environ Microbiol 66, 467-475.

Edwards, U., Rogall, T., Blocker, H., Emde, M. \& Bottger, E. C. (1989). Isolation and direct complete nucleotide determination of entire genes. Characterization of a gene coding for $16 \mathrm{~S}$ ribosomal RNA. Nucleic Acids Res 17, 7843-7853.

Ezaki, T., Hashimoto, Y. \& Yabuuchi, E. (1989). Fluorometric deoxyribonucleic acid-deoxyribonucleic acid hybridization in microdilution wells as an alternative to membrane filter hybridization in which radioisotopes are used to determine genetic relatedness among bacterial strains. Int J Syst Bacteriol 39, 224-229.

Faimali, M., Chelossi, E., Garaventa, F., Corrà, C., Greco, G. \& Mollica, A. (2008). Evolution of oxygen reduction current and biofilm on stainless steels cathodically polarized in natural aerated seawater. Electrochim Acta 54, 148-153.

González, J. M. \& Moran, M. A. (1997). Numerical dominance of a group of marine bacteria in the $\alpha$-subclass of the class Proteobacteria in coastal seawater. Appl Environ Microbiol 63, 4237-4242.

González, J. M., Whitman, W. B., Hodson, R. E. \& Moran, M. A. (1996). Identifying numerically abundant culturable bacteria from complex communities: an example from a lignin enrichment culture. Appl Environ Microbiol 62, 4433-4440.

González, J. M., Simo, R., Massana, R., Covert, J. S., Casamayor, E. O., Pedros-Alio, C. \& Moran, M. A. (2000). Bacterial community structure associated with a dimethylsulfoniopropionate-producing North Atlantic algal bloom. Appl Environ Microbiol 66, 4237-4246.

Hall, T. A. (1999). BioEdit: a user-friendly biological sequence alignment editor and analysis program for Windows 95/98/NT. Nucleic Acids Symp Ser 41, 95-98.

Inagaki, F., Suzuki, M., Takai, K., Oida, H., Sakamoto, T., Aoki, K., Nealson, K. H. \& Horikoshi, K. (2003). Microbial communities associated with geological horizons in coastal subseafloor sediments from the Sea of Okhotsk. Appl Environ Microbiol 69, $7224-7235$

King, G. M. (2003). Molecular and culture-based analyses of aerobic carbon monoxide oxidizer diversity. Appl Environ Microbiol 69, 72577265 .

Martens, T., Heidorn, T., Pukall, R., Simon, M., Tindall, B. J. \& Brinkhoff, T. (2006). Reclassification of Roseobacter gallaeciensis RuizPonte et al. 1998 as Phaeobacter gallaeciensis gen. nov., comb. nov., description of Phaeobacter inhibens sp. nov., reclassification of Ruegeria algicola (Lafay et al. 1995) Uchino et al. 1999 as Marinovum algicola gen. nov., comb. nov., and emended descriptions of the genera Roseobacter, Ruegeria and Leisingera. Int J Syst Evol Microbiol 56, 1293-1304.

Martens, T., Gram, L., Grossart, H. P., Kessler, D., Müller, R., Simon, M., Wenzel, S. C. \& Brinkhoff, T. (2007). Bacteria of the
Roseobacter clade show potential for secondary metabolite production. Microb Ecol 54, 31-42.

Mast, J., Nanbru, C., Van Den Berg, T. \& Meulemans, G. (2005). Ultrastructural changes of the tracheal epithelium after vaccination of day-old chickens with the La Sota strain of Newcastle disease virus. Vet Pathol 42, 559-565.

Mergaert, J., Verhelst, A., Cnockaert, M. C., Tan, T. L. \& Swings, J. (2001). Characterization of facultative oligotrophic bacteria from polar seas by analysis of their fatty acids and $16 \mathrm{~S}$ rDNA sequences. Syst Appl Microbiol 24, 98-107.

Mesbah, M., Premachandran, U. \& Whitman, W. B. (1989). Precise measurement of the $\mathrm{G}+\mathrm{C}$ content of deoxyribonucleic acid by highperformance liquid chromatography. Int J Syst Bacteriol 39, 159-167.

Moran, M. A., Gonzalez, J. M. \& Kiene, R. P. (2003). Linking a bacterial taxon to sulfur cycling in the sea: studies of the marine Roseobacter group. Geomicrobiol J 20, 375-388.

Moran, M. A., Buchan, A., Gonzalez, J. M., Heidelberg, J. F., Whitman, W. B., Kiene, R. P., Henriksen, J. R., King, G. M., Belas, R. \& other authors (2004). Genome sequence of Silicibacter pomeroyi reveals adaptations to the marine environment. Nature 432, 910-913.

Pitcher, D. G., Saunders, N. A. \& Owen, R. J. (1989). Rapid extraction of bacterial genomic DNA with guanidium thiocyanate. Lett Appl Microbiol 8, 151-156.

Rademaker, J. L. W. \& De Bruijn, F. J. (1997). Characterization and classification of microbes by rep-PCR genomic fingerprinting and computer-assisted pattern analysis. In DNA Markers: Protocols, Applications, and Overviews, pp. 151-171. Edited by G. CaetanoAnollès \& P. M. Gresshoff. New York: Wiley.

Raes, J. \& Van De Peer, Y. (1999). ForCon: a software tool for the conversion of sequence alignments. http://www.ebi.ac.uk/embnet.news/vol6_1/ForCon/body_forcon.html

Reichenbach, H. \& Dworkin, M. (1981). Introduction to the gliding bacteria. In The Prokaryotes, vol. 1, pp. 315-327. Edited by M. P. Starr, H. Stolp, H. G. Trüper, A. Balows \& H. G. Schlegel. Berlin: Springer.

Rüger, H. J. \& Höfle, M. G. (1992). Marine star-shaped-aggregateforming bacteria: Agrobacterium atlanticum sp. nov.; Agrobacterium meteori sp. nov.; Agrobacterium ferrugineum sp. nov., nom. rev.; Agrobacterium gelatinovorum sp. nov., nom. rev.; and Agrobacterium stellulatum sp. nov., nom. rev. Int J Syst Bacteriol 42, 133-143.

Ruiz-Ponte, C., Cilia, V., Lambert, C. \& Nicolas, J. L. (1998). Roseobacter gallaeciensis sp. nov., a new marine bacterium isolated from rearings and collectors of the scallop Pecten maximus. Int J Syst Bacteriol 48, 537-542.

Saitou, N. \& Nei, M. (1987). The neighbor-joining method: a new method for reconstructing phylogenetic trees. Mol Biol Evol 4, 406425.

Schaefer, J. K., Goodwin, K. D., McDonald, I. R., Murrell, J. C. \& Oremland, R. S. (2002). Leisingera methylohalidivorans gen. nov., sp. nov., a marine methylotroph that grows on methyl bromide. Int J Syst Evol Microbiol 52, 851-859.

Selje, N., Simon, M. \& Brinkhoff, T. (2004). A newly discovered Roseobacter cluster in temperate and polar oceans. Nature 427, 445448.

Shiba, T. (1991). Roseobacter litoralis gen. nov., sp. nov., and Roseobacter denitrificans sp. nov., aerobic pink-pigmented bacteria which contain bacteriochlorophyll a. Syst Appl Microbiol 14, 140-145.

Sierra, G. (1957). A simple method for the detection of lipolytic activity of microorganisms and some observations on the influence of the contact between cells and fatty substrates. Antonie van Leeuwenhoek 23, 15-22. 
Suzuki, M. T., Preston, C. M., Chavez, F. P. \& DeLong, E. F. (2001). Quantitative mapping of bacterioplankton populations in seawater: field tests across an upwelling plume in Monterey Bay. Aquat Microb Ecol 24, 117-127.

Tan, T. L. \& Rüger, H. J. (1999). Enrichment, isolation, and Biolog metabolic fingerprints of oligotrophic bacteria from the Antarctic Ocean. Arch Hydrobiol Spec Issues Adv Limnol 54, 255-272.

Thompson, J. D., Gibson, T. J., Plewniak, F., Jeanmougin, F. \& Higgins, D. G. (1997). The CLUSTAL_X windows interface: flexible strategies for multiple sequence alignment aided by quality analysis tools. Nucleic Acids Res 25, 4876-4882.

Uchino, Y., Hirata, A., Yokota, A. \& Sugiyama, J. (1998). Reclassification of marine Agrobacterium species: proposals of Stappia stellulata gen. nov., comb. nov., Stappia aggregata sp. nov., nom. rev., Ruegeria atlantica gen. nov., comb. nov., Ruegeria gelatinovora comb. nov., Ruegeria algicola comb. nov., and Ahrensia kieliense gen. nov., sp. nov., nom. rev. J Gen Appl Microbiol 44, 201-210.
Van De Peer, Y. \& De Wachter, R. (1994). TREECON for Windows: a software package for the construction and drawing of evolutionary trees for the Microsoft Windows environment. Comput Appl Biosci 10, 569-570.

Vandecandelaere, I., Nercessian, O., Segaert, E., Achouak, W., Mollica, A., Faimali, M., De Vos, P. \& Vandamme, P. (2008). Alteromonas genovensis sp. nov., isolated from a marine electroactive biofilm and emended description of Alteromonas macleodii Baumann et al. 1972 (Approved Lists 1980). Int J Syst Evol Microbiol 58, 25892596.

Versalovic, J., Schneider, M., De Bruijn, F. J. \& Lupski, J. R. (1994). Genomic fingerprinting of bacteria using repetitive sequence-based polymerase chain reaction. Methods Mol Cell Biol 5, 25-40.

Yoon, J. H., Kang, S. J., Lee, S. Y. \& Oh, T. K. (2007). Phaeobacter daeponensis sp. nov., isolated from a tidal flat of the Yellow Sea in Korea. Int J Syst Evol Microbiol 57, 856-861. 